\title{
GEOLOGIC MAP OF THE LUCERNE VALLEY QUADRANGLE SAN BERNARDINO COUNTY, CALIFORNIA By
} T. W. Dibblee, Jr.

MISCELLANEOUS GEOLOGIC INVESTIGATIONS MAP I-426

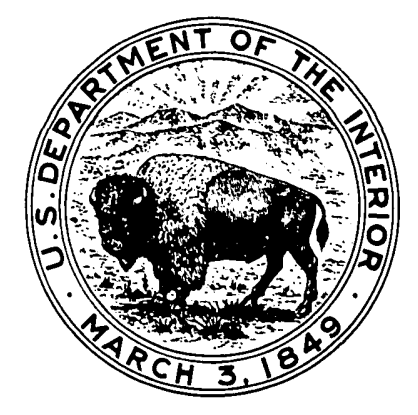




\title{
GEOLOGIC MAP OF THE LUCERNE VALLEY QUADRANGLE
}

\author{
SAN BERNARDINO COUNTY, CALIFORNIA
}

By T. W. Dibblee, Jr.

\section{DESCRIPTION OF MAP UNITS}

\section{PRECAMBRIAN(?) METAMORPHIC ROCKS}

\section{Gneissic rocks}

Unit includes Baldwin Gneiss of Guillou (1953, p. 6). Fine-, medium-, and coarse-grained, composed mostly of quartz, potassic feldspar (orthoclase and microcline), plagioclase (andesine), and biotite in variable proportions, in places contains hornblende, or muscovite; prominently to faintly laminated; laminae generally undulating, in places contorted; in secs. 27, 28,33, T. 4 N., R. 2 E., rocks have lineation pitching about $45^{\circ} \mathrm{NW}$. Age, probably Precambrian. Two units of gneissic rocks mapped as follows:

Quartz diorite gneiss.--Gray, generally prominently banded with black laminae rich in biotite and (or) hornblende, alternating with white laminae rich in quartz and feldspars (mostly plagioclase), and with gray laminae of intermediate composition. In places rock contains augen as large as $2 \mathrm{~cm}$ by $5 \mathrm{~cm}$ of pink orthoclase with quartz, elongated parallel to banding, also minute sills and dikes of pink pegmatite. In places rock is gray white, fine to medium grained, composed mostly of quartz and feldspars, with faint bands rich in biotite; probably of quartz monzonite composition.

Gneiss and schist.--Exposed in Blackhawk Canyon. Similar to quartz diorite gneiss, but includes some gradations to dark-gray, fine-to medium-grained schist rich in biotite or rich in biotite and quartz, or biotite and feldspar. In places migmatized. Possibly recrystallized from Saragossa Quartzite.

\section{PALEOZOIC METASEDIMENTARY ROCKS}

\section{Saragossa Quartzite}

Predominantly quartzite, but includes some phyllite and schist. Named by Vaughan (1922, p. 344, 352 363 , and map) for Saragossa Spring. Type locality hereby designated as sequence exposed southeast of Saragossa Spring on Gold Mountain. Includes Chicopee Formation of Guillou (1953, p. 7-10) and Chicopee Canyon Formation of Richmond (1960, p. 11-15). Total thickness about 1,600 feet at type locality; about 1,300 feet in Chicopee Canyon; 1,320 feet measured at Dela- mar Mountain (Richmond, 1960, p. 12). Also includes Arrastre Quartzite of Vaughan (1922, p. 344,351-365, and map) in lower Arrastre Creek area, where exposed sequence is at least 1,500 feet thick. Unconformably overlies gneissic rocks; overlain by Furnace Limestone; intruded by quartz monzonite. Unfossiliferous. Age, presumably Paleozoic. The following facies units were mapped:

Quartzite.--White to gray, commonly with pink to brown iron-staining on fractures, massive to bedded, locally cross-laminated or ripple-marked, very hard, brittle, siliceous, fine-grained; composed mostly of quartz and minor amounts of muscovite, biotite, alkalic feldspars, and iron oxides. Upper 350 feet of upper unit nearly all white, massive; rest of quartzite contains interbedded micaceous quartzite and dark quartzitic phyllite; lowest part contains some calc-silicate hornfels; southeast of Baldwin Lake basal few feet of Saragossa Quartzite bedded, contains granitic grit and small pebbles.

Phyllite.--Mostly dark-gray, hard, shaly, thinbedded, micaceous to quartzitic phyllite; contains some interbedded dark-gray micaceous quartzite. Forms unit about 350 feet thick in middle part of formation in Chicopee Canyon area.

Gneissic quartzite.--Part of Arrastre Quartzite of Vaughan (1922). Generally similar in color and composition to quartzite, but more severely metamorphosed to leucocratic gneissic quartzite with aplitic texture; rock nearly romogeneous, massive to faintly banded with darker biotite-rich laminae that may be relict bedding. In places rock has lineation.

Schist.--Part of Arrastre Quartzite of Vaughan (1922). Dark-gray, fine-grained, composed mostly of biotite, feldspar, and quartz; commonly banded with black biotite-rich laminae alternating with white quartzitic laminae, in places rock approaches finegrained gneiss in texture; foliation parallel to bedding; in places rock lineated. Contains some interbedded gray quartzite.

Marble.--Gray-white, thick-bedded, medium to coarsely crystalline. Forms bed as thick as 70 feet near top of formation in Arrastre Creek area. 
Furnace Limestone

Named by Vaughan $(1922$, p. $344,352-365$, and map) for exposures in Furnace Canyon, the type locality; called Furnace Formation by Richmond (1960, p. 14-24, and pl. 1). Mostly marblized carbonate rocks that range from limestone to dolomite, distinguishable only by acid test. On Delamar Mountain and Johnston Grade areas, conformable on Saragossa Quartzite; elsewhere intruded by igneous rocks; top eroded; in Furnace Canyon area, about 3,000 feet exposed; on west side of Cushenbury Canyon, about 5,000 feet. North of Holcomb Valley dark-gray carbonate rocks contain crinoid fragments, bryozoans; also Caninia sp. (coral), Eumetria cf. altirostris White, Dictyoclostus sp., and Spirifer cf. centronatus (brachiopods) suggestive of Mississippian age (Richmond, 1960, p. 17-18). The following facies units were mapped:

White carbonate rocks.--White to pale-gray, medium to very coarsely crystalline (2 - to $4-\mathrm{mm}$ grain size) limestone or dolomite marble, thick-bedded to massive; in places contains metamorphic minerals such as tremolite, epidote, diopside, and forsterite.

Gray carbonate rocks.--Blue-black to blue-gray, mostly fine but locally medium to coarsely crystalline limestone or dolomite marble, commonly banded with white laminae.

Phyllite.--Dark-gray, hard, platy, somewhat schistose, fine-grained, micaceous; forms lenses as thick as 50 feet.

Quartzite.--Gray-white, massive, very hard, siliceous; forms lenses as thick as 100 feet.

\section{MESOZOIC PLUTONIC AND HYPABYSSAL IGNEOUS ROCKS}

Older granitic rocks

Granitic rocks, mainly of quartz monzonite composition but ranging from granite to granodiorite. Age, Mesozoic, presumably Late Jurassic or Early Cretaceous. Composed of the following units:

Aplitic quartz monzonite.--Buff but with brown iron staining on fractures, massive, hard, very finegrained. Composed of about 40 percent quartz, 20 percent orthoclase, 30 percent plagioclase (oligoclase), and a total of about 10 percent sphene, biotite, muscovite, and apatite, and contains a few very small phenocrysts of plagioclase (Guillou, 1953, p. 12); forms small bodies in Cushenbury Canyon.

Granite and quartz monzonite. - -Nearly white but weathers buff to light gray, hard, massive except slightly gneissoid at Pitzer Butte, medium- to locally coarse-grained. Ranges in composition from granite to quartz monzonite. Composed of quartz, potassic feldspar, and plagioclase (oligoclase) in nearly equal proportions with slight predominance of potassic feldspar, 1 to 2 percent of biotite (as minute flakes), 0 to 2 percent hornblende (both biotite and hornblende locally partly altered to brown iron oxides by weather ing), and a total of about 1 percent of sphene, zircon, and iron oxides.

Migmatized quartz monzonite.--Composed of scattered to numerous xenoliths, streaks, and irregular lenses of light - to dark-gray quartz monzonite intricately mixed and injected by gray-white quartz monzonite. Both rocks composed of quartz, microcline, and oligoclase in nearly equal proportions, biotite and traces of sphene, apatite, muscovite, hornblende, magnetite; darker rocks massive to faintly banded, finer grained, richer in biotite and hornblende, contain some chlorite and sericite, and partly resorbed phenocrysts about $3 \mathrm{~mm}$ long of oligoclase, microcline, and quartz in that order of decreasing abundance (Richmond, 1960, p. 43). Darker rocks recrystallized from metamorphic rocks or basic plutonic rocks.

Hornblende quartz monzonite. --Light-gray, mas sive to rarely gneissoid, mylonitized for about 200 feet at north contact west of Holcomb Creek; hard, medium-grained (average grain size about $2 \mathrm{~mm}$ ). Composed of from 2 to 15 percent quartz, 20 to 35 percent microcline, 30 to 40 percent plagioclase (oligoclase or andesine), 15 to 25 percent hornblende, 2 to 5 percent sphene, traces of apatite, magnetite, and rutile, biotite rare, sericite common as alteration from feldspars, and epidote and chlorite as alteration of hornblende; specific gravity 2.68 to 2.79 , average 2.72 (Richmond, 1960, p. 33-34).

Biotite quartz monzonite.--Light- to mediumgray, massive to somewhat gneissoid, medium-grained, porphyritic. Ranges in composition from quartz monzonite to granodiorite, composed of quartz, potassic feldspar, and plagioclase (oligoclase or andesine) in about equal proportions or with slight predominance of plagioclase, 5 to 20 percent biotite (mostly as clusters of small flakes), 0 to 5 percent hornblende, and a total of about 1 percent iron oxides, sphene, apatite, and zircon. Porphyritic facies contains scattered to abundant (20 percent of rock mass) phenocrysts of potassic feldspar as long as $2 \mathrm{~cm}$.

Granodiorite.--Light-gray, gneissoid to massive, medium-grained. Composed of about 25 percent quartz, 25 percent potassic feldspar, 40 percent plagioclase (oligoclase or andesine), 8 percent biotite, and total of about 2 percent hornblende, sphene, zircon, and iron oxides. Biotite in moderately large flakes oriented parallel to gneissoid foliation. Rock presumable facies of biotite quartz monzonite and probably recrystallized from associated gneiss.

\section{Hornblende diorite and gabbro}

Dark-gray to black, massive, medium-to coarsegrained, composed of from 45 to 60 percent plagioclase (An37 to An77), 40 to 55 percent hornblende (partly altered to biotite, chlorite, and epidote), and small amounts of magnetite, sphene, apatite, quartz, and orthoclase (Richmond, 1960, p. 20). Forms small bodies engulfed in quartz monzonite. Age, Mesozoic. 


\section{Porphyry complex}

Complex of slightly metamorphosed porphyritic aphanitic to fine-grained igneous rocks. Forms large elongated mass, and dikes intrusive into metasedimentary rocks and gneiss. Relation to older granitic rocks uncertain; probably intruded by quartz monzonite; porphyritic rocks probably emplaced at different times during Mesozoic Era. Composed of the following units:

Granite porphyry.--Gray, with brown iron staining on fractures, massive, hard. Phenocrysts scattered to abundant (10 to 50 percent of rock mass), generally small (average $2 \mathrm{~mm}$ long) but some as long as $5 \mathrm{~mm}$ with sharp to partly resorbed borders, most are of microcline-microperthite, others of plagioclase (oligoclase), quartz, and biotite; groundmass very fine grained, aplitic, composed of microcline-microperthite and quartz, and traces of biotite, magnetite, sphene, and apatite; specific gravity 2.58 to 2.61 (Richmond, 1960, p. 40). Rock gradational into quartz latite porphyry.

Quartz latite porphyry.--Gray, with brown iron staining on fracture surfaces, very hard, massive, rarely flow laminated. Generally composed of scattered phenocrysts ( 5 to 15 percent of rock, 1 to $3 \mathrm{~mm}$ long), of plagioclase (albite or oligoclase), potassic feldspar, and rarely quartz, in microcrystalline groundmass of quartz, sericite, saussuritized feldspar, and minor amounts of sphene, magnetite, and biotite; specific gravity 2.60 to 2.66 (Richmond, 1960 , p. 25-27). Includes light-gray to black facies (lithic crystal quartz latite tuff) with crystal fragments of feldspar in microspherulitic or vitroclastic groundmass, and local dikes of dark-gray trachyandesite with phenocrysts of oligoclase and amygdules filled with biotite and feldspar in felspathic groundmass containing magnetite, calcite, epidote, apatite, biotite, and quartz (Richmond, 1960, p. 26-27).

\section{Diorite}

Dark-gray, massive, fine-grained, composed mainly of calcic plagioclase and hornblende, and scattered phenocrysts of plagioclase. Forms lenticular dikes as wide as 15 feet in granite and quartz monzonite. Age, Mesozoic.

\section{Quartz diorite}

Dark-gray, massive, somewhat friable where weathered, medium-grained; composed of 10 to 20 percent quartz, 0 to 10 percent orthoclase, 30 to 50 plagioclase (andesine), total of 30 to 50 percent biotite and hornblende (partly altered to chlorite) in nearly equal amounts, and total of less than 5 percent of sphene; magnetite, and ilmenite (Guillou, 1953, p. 12-13). In area north of Big Bear Lake, rock varies from medium to fine grained and locally contains scattered phenocrysts of plagioclase (andesine) as long as $3 \mathrm{~mm}$. Age, Mesozoic, possibly mafic facies of quartz monzonite, but in most places apparently intruded by it and therefore probably older.

\section{Quartz monzonite}

(Includes Cactus Granite of Vaughan, 1922, p. $344,364-365$; biotite quartz monzonite and granite cataclasite of Richmond, 1960, p. 35-39). Gray-white, weathers buff, hard but friable where weathered, massive, generally equigranular, rarely subporphyritic, medium - to coarse-grained (average grain size $3 \mathrm{~mm}$ ), composed of quartz, potassic feldspar (orthoclase or microcline, locally perthite), and plagioclase (oligoclase or andesine) in generally equal proportions, 3 to 7 percent biotite (generally as scattered euhedral tablets 1 to $3 \mathrm{~mm}$ in diameter), and a total of less than 2 percent of sphene, apatite, zircon, magnetite, and (rarely) hornblende. In foothills between Silver and Crystal Creeks, rock cataclastically fractured and sericitized. Rock probably intrusive into all other pre-Tertiary rocks. Age, Mesozoic, possibly Late Jurassic but probably Early Cretaceous.

\section{Quartz pods}

Pods or lenses as thick as 50 feet, and as long as 150 feet, of white milky quartz. Occurs at several places within gneiss. Age, pre-Tertiary, presumably Mesozoic but may be older.

CENOZOIC SEDIMENTARY AND VOLCANIC ROCKS

\section{Old Woman Sandstone}

Named by Shreve in Richmond (1960, p. 45-46). Mainly arkosic sandstone, lesser amounts of interbedded conglomerate and siltstone. Conglomerate composed of rounded cobbles and pebbles of preTertiary(?) porphyritic and felsitic rocks, granitic rocks, quartzite, gneiss, quartz, Tertiary andesite and basalt, and (rarely) Furnace Limestone, in that order of decreasing abundance, in light gray-brown sandstone matrix. Sandstone, light-buff to reddishbuff, bedded to massive, friable, medium - to finegrained, commonly conglomeratic. Siltstone, light reddish-brown to greenish-gray, crumbly, sandy to argillaceous, commonly contains small calcareous nodules, in places contains strata as thick as 2 feet of white marl. One mile north of Blackhawk Mountain in lower Blackhawk Canyon (type locality) mostly sandstone. Maximum exposed thickness about 600 feet, but unconformably overlain by Pleistocene fanglomerate and landslide rubble. In low hills 2 to 6 miles southeast of town of Lucerne. Valley, mostly conglomerate and sandstone with 3 feet of white marl near top; maximum thickness of sequence about 1,000 feet; top eroded. Elsewhere mostly sandstone and lesser amounts of siltstone and conglomerate. Probably derived mostly from areas north of Lucerne Valley, as suggested by large amounts of pre-Tertiary porphyritic detritus and scarcity of Furnace Limestone fragments. Unconformable on pre-Tertiary rocks. Age, Tertiary, most probably late Tertiary.

\section{Basalt}

Black, massive, hard, nonvesicular. Composed of scattered irregular grains of olivine and a few small 
phenocrysts of plagioclase in microcrystalline groundmass. Maximum thickness about 70 feet. In part extruded from vent at Negro Butte. Unconformable on quartz monzonite. Age, presumably Pliocene or early Pleistocene.

\section{Older surficial sediments}

Older alluvial deposits derived mostly from San Bernardino Mountains. Weakly indurated; dissected where elevated; locally deformed. Age, Pleistocene. Composed of the following units or facies:

Older alluvium. --Cobble gravel and sand, poorly bedded to nonbedded. In northwest part of quadrangle, composed of detritus of granite and quartz monzonite, in northeast part fragments mostly of basalt and quartz monzonite. Maximum exposed thickness about 100 feet, maximum concealed thickness under alluvium of Lucerne Valley may be several hundred feet.

Older fanglomerate.--Gray, poorly to wellbedded, composed of poorly sorted subrounded fragments as large as 3 feet in diameter in fragmental matrix. In Holcomb Valley, hills south of Big Bear City, and vicinity of Johnston Grade, fragments mostly of quartzite. In area west of Crystal Creek and east of Arrastre Creek fragments mostly of granitic rocks. Elsewhere fragments mostly of Furnace Limestone, with some layers well indurated by calcareous cement. Maximum exposed thickness about 500 feet. Northward under alluvium of Lucerne Valley, fanglomerate presumably thickens and grades laterally into older alluvium.

Landslide rubble. --North and northeast of Black hawk Mountain (where mapped as Blackhawk Breccia by Woodford and Harris, 1928, p. 279-283) composed entirely of brecciated dark-gray and white Furnace Limestone of that mountain. In part overlain and in part underlain by older fanglomerate. Maximum thickness of landslide about 400 feet, probably overlies older alluvium in Lucerne Valley. Other small landslides in San Bernardino Mountains composed of rubble from rocks immediately upslope.

Terrace gravels.--Cobble-boulder gravel of mostly limestone detritus, poorly bedded, weakly indurated, thickness about 150 feet, unconformable on fanglomerate and Olḍ Woman Sandstone.

\section{Surficial sediments}

Unconsolidated sediments of undissected fill of valley areas. In valley area gradational into underlying older surficial sediments where present; elsewhere unconformable on older formations. Age, very late Pleistocene and Recent. Composed of the following facies:

Fanglomerate.--Composed of unsorted angular to subrounded fragments as large as 5 feet in diameter derived from pre-Tertiary rocks of San Bernardino Mountains. Downslope from base of mountains fragments decrease in size and facies grades into alluvium.
Alluvium.--Gravel, sand, and silt derived from adjacent higher ground.

Clay.--Micaceous, silty to argillaceous, fills playa lakes.

Sand.--Fine-grained, composed of quartz and feldspar, deposited by prevailing west winds.

\section{MINES AND QUARRIES \\ Gold}

A. Gold Button mine. Skz sec. 4, T. 3 N., R. 1 W. Gold values, with some lead, silver, and copper, reportedly disseminated in fault-gouge zone between cataclastic quartz monzonite to south and fanglomerate to north; fault dips $70^{\circ}$ to $90^{\circ} \mathrm{S}$. Developed prior to 1930 by three adits driven south 75,100 , and 300 feet with drifts along zone, 300 -foot adit and 100-foot raise to surface. (Gray, 1960, p. 61, no. 10)

B. J. A. W. mine. NW/4 sec. 9, T. 3 N., R. 1 W. Iron-stained shear zone in migmatized quartz monzonite. Explored by three adits driven southwest 50 to $200 \mathrm{feet}$, and vertical shaft. No gold found. (Gray, 1960 , p. 63 , no. 17)

C. Wright mine. SE/4 sec. $17, \mathrm{SW} / 4 \mathrm{sec} .16$ ?, T. 3 N., R. 1 W. Gold reportedly disseminated in quartz veins striking southwest and southeast in sheared, locally mylonitized hornblende quartz monzonite. Prospected by two adits driven southwest and southeast along veins; fine-stamp mill. (Wright and others, 1953 , tab. list p. 63 , no. 205; Gray, 1960 , p. 65 , no. 33)

D. Greenlead mine. NE/4 sec. 28, NW/4 sec. 27, T. 3 N., R. 1 W. Gold and silver, copper stains reportedly disseminated in quartz vein 2 to 4 feet wide, strikes northwest along contact between hornblende quartz monzonite and Furnace Limestone. Explored intermittently from 1894 to 1898 by 400 -foot shaft with levels at $50,100,200,300$, and 400 feet, and by adit driven southeast 370 feet. (Wright and others, 1953, tab. list p. 41, no. 121; Gray, 1960, p. 61 , no. 11)

E. Desert View mine. NE/4 sec. 27, T. 3 N., R. $1 \mathrm{~W}$. Gold reportedly disseminated in skarn zone of massive specular hematite and coarse epidote in Furnace Limestone. Explored by 30 -foot crosscut adit driven east to intersect skarn zone. (Gray, 1960, p. 60)

F. Ozier mine. SE⿺/4 sec. 20, T. 3 N., R. 1 E. Gold in hematite-rich southwest-dipping fracture zone in quartz monzonite. Opened in late 1850's, reportedly most active from 1860 to 1890 , idle since $1900(?)$; developed by mâny adits and shallow shafts, deepest probably 75 to 100 feet, with level workings, now caved. Gold output unknown, but probably substantial. (Wright and others, 1953, p. 77,78 , tab. list p. 52, no. 162; Gray, 1960, p. 64, no. 25)

G. Harvey K. (Hepburn) mine. SW/4 sec. 29, T. 3 N., R. 1 E. Gold disseminated in locally siliceous 
fracture zone and in 4 - to 6 -foot-wide quartz veins in quartz monzonite. Developed by inclined shaft, possibly as deep as 200 feet with short drifts. Small tonnage of gold ore shipped, probably in 1890's. (Wright and others, 1953, tab. list p. 41, no. 124; Gray, 1960, p. 61 , no. 13)

H. Independence mine. NKz sec. $33, T, 3$ N., R. 1 E. Gold, pyrite, chalcopyrite, disseminated in quartz vein 1 to 12 inches wide in quartz monzonite. Explored from 1955 to 1958 by 75-foot adit along footwall of vein and 15-foot shaft from adit. Ten tons of ore shipped. (Gray, 1960, p. 62, no. 16)

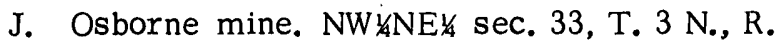
$1 \mathrm{E}$. Gold disseminated in quartz vein 1 to 4 feet wide, strikes N. $60^{\circ}$ W., dips N., as long as 500 feet, in quartz monzonite. Explored in late $1880^{\prime} \mathrm{s}$ by $40^{\circ}$ inclined shaft sunk on vein, by workings to east mostly within 300 feet of shaft and above 60 -foot level, and by shallow workings for 400 feet along a second vein to north. (Wright and others, 1953, p. 77, tab. list p. 52, no. 160; Gray, 1960, p. 63, no. 24)

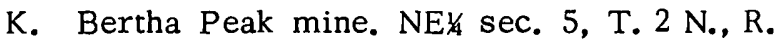
1 E. Gold reported along contact of Saragossa Quartzite and granite porphyry. Prospected in 1890's(?) by 260-foot adit and three others of unknown length, now caved. (Gray, 1960, p. 60, no. 1)

L. Blue Quartz mine. SEžnW 4 sec. 10, T. 2 N., R. 1 E. Iron-stained quartz veins few inches thick, possibly carrying gold, in quartz monzonite near contact with Furnace Limestone to north. Explored by adit driven north to quartz veins.

M. Doble (Gold Mountain) mine. SW/4NE $/ 4$ sec. 36, T. 3 N., R. 1 E. Gold disseminated in sheared and shattered iron-stained quartzite along fault zone dipping about $40^{\circ} \mathrm{SW}$ between Saragossa Quartzite to southwest, and phyllite and quartzite to northeast. Mined from open cut along 600 feet long, and from slopes along tunnel driven along shear zone. Operated in late 1800's by Lucky Baldwin; worked occasionally from 1900 to 1951 , when it yielded between $\$ 250,000$ and $\$ 300,000$ in gold; abandoned in 1951. (Wright and others, 1953, tab. list p. 32, no. 92; Guillou, 1953, p. 16)

N. Gold Hill mine. S'N/4 sec. 17, T. 2 N., R. 2 E. Series of parallel thin quartz veins, possible carrying gold, along bedding planes in Saragossa Quartzite. Prospected by crosscut adit driven northeast 1,200 feet, with 200 feet of drifts, and several short adits, shafts, and cuts. May have yielded small tonnage of gold ore. (Wright and others, tab. list p. 37, no. 109)

P. Santa Fe mine (175 claims). Secs. 8, 16, 17, 18 (projected), T. 3 N., R. 2 E., north slope of Blackhawk Mountain. Gold disseminated in zone as thick as 100 feet of red, hematite-stained, brecciated and sheared limestone along thrust fault between Furnace Limestone above and gneiss and schist below and to north, thrust fault dips south at low angle. Mined from open cuts and from at least nine adits from 2,500 to 3,000 feet in combined length. Some gold also disseminated in basal 75 feet to brecciated and sheared limestone of large landslide on west wall of Blackhawk Canyon; mined from more than 1,200 feet of adits and raises (Cliff mine). Mines operated for a few years after 1887 by Blackhawk Company. Operated nearly continuously from 1921 to 1940 by Arlington Mining Corp., which built a 1,600-ton cyanide mill at $\mathrm{S} / 2 \mathrm{sec}$. 8 at mouth of Blackhawk Canyon, and reported output of $\$ 300,000$ in value. (Wright and others, 1953, p. 80 , tab. list p. 56, no. 178)

Q. Lester (Dail) mine. NE/4NE/4 sec. 21, T. 3 N., R. 2 E. Gold disseminated in two quartz veins in hornblende diorite and quartz diorite. Mined from several short tunnels and shallow shafts; ore milled at small cyanide mill. Opened probably in late 1920's; small shipment in 1952. (Wright and others, 1953, tab. list p. 46 , no. 138)

R. Holcomb Valley placers. Secs. 29, 30, 31, 32, 33 , T. 3 N., R. 1 E. Detrital gold sparsely distributed in gravels of both Recent and older alluvium. Mined from numerous shallow diggings. Extensively and profitably worked for a few years following discovery in 1860; intermittently worked since; unsuccessfully worked by Holcomb Valley Co., Ltd., an English concern, in late 1880's and early 1890's; worked as late as 1930's; lack of water a hindrance. (Wright and others, 1953, tab. list p. 42-43, no. 128; Gray, 1960, p. 51-64)

\section{Silver-Gold}

S. Akron - Silver Reef mine. Sec. 3, Włz sec. 2, T. 3 N., R. 2 E. Silver bromide and silver chloride minerals and subordinate gold sparsely distributed in red hematite-stained matrix of brecciated and sheared Furnace Limestone rubble, mostly in basal part of Quaternery landslide rubble. Mined from open cuts and shallow adits; worked occasionally prior to 1952 , reportedly worked prior to 1900 . No output recorded. (Wright and others, 1953, tab. list p. 96, no. 299)

T. Mohawk (Nigger Mountain) mine. NW $/ 4 \mathrm{sec}$. 23, T. 3 N., R. 1 E. Few irregular lenses of ore minerals, mostly galena and sphalerite, in iron-oxiderich zone as wide as 15 feet and traceable for at least 1,000 feet north-south, dips steeply west, in marble of Furnace Limestone near contact with quartz monzonite to southwest. Mines from adit driven west to zone, with about 700 feet of drifts and crosscuts, and another adit about 700 feet higher driven west about 180 feet. Worked occasionally since 1909, yielded about 80 tons of lead-zinc-silver ore during World War II; idle since 1946. (Wright and others, 1953, p. 111 , tab. list p. 81 , no. 266)

U. Scotty Wilson mine. SE/4 sec. $4, T .2$ N., R. 1 E. Small irregular masses composed mostly of 
galena, pyrite, and sphalerite, and also some radioactive minerals (including pitchblende) unevenly distributed in lenses of limestone as long as several tens of feet, within vertical 30-foot-wide fault zone striking N. $60^{\circ}$ E. in Furnace Limestone. Mined in 1930 's, intermittently since, from 30-foot shaft and adit driven south, with output of several tons of leadsilver-zinc ore; workings now caved. In 1951 mined from 50-foot shaft about 20 feet east of old shaft, with two short crosscuts driven south. (Wright and others, 1953, tab. list p. 83, no. 271)

\section{Limestone}

V. Van Dusen Company quarry. NW $144 \mathrm{SW} / 4$ sec. 3 , T. 2 N., R. 1 E. White to pale gray fine-grained dolomitic marble of Furnace Limestone. Small tonnage quarried in 1950 for use as roofing granules. (Wright and others, 1953, p. 180)

W. Anchor Minerals and Chemicals, Inc. (formerly Victorville Lime Rock Company) quarries. Sec. 13 , T. 3 N., R. 1 W. Several quarries in white marble of Furnace Limestone complexly folded, intruded by quartz monzonite. Marble quarried since 1959 for use as roofing granules; milled at crushing plant in sec. 1, T. 3 N., R. 1 W. (Gray, 1960, p. 67, in part)

Z. Permanente Cement Company of Kaiser Steel Corp., Cushenbury plant and quarries. SE 14 sec. 10, SW $4 / 4$ sec. 11, T. 3 N., R. 1 . E. (cement plant); NW/4 sec. $14, N E / 4$ sec. 15, T. 3 N., R. 1 E. (quarries). Large quarries in bedded gray fine-grained Furnace Limestone folded into anticline plunging west. Quarries opened in 1957 with more than 1,000,000 tons of limestone quarried annually since, milled in two large kilns at plant with annual production capacity of $2,700,000$ barrels of cement. In 1962-1963 another large kiln installed with additional production capacity of 2,700,000 barrels of cement. (Gray, 1960, p. 56-57, in part)

AA. Cushenbury Canyon (Dunton) quarry. SW1/4 sec. 13 (projected), NW/4 sec. 24 (projected), T. 3 N., R. 1 E. White coarsely crystalline limestone, about 50 feet thick, in gray Furnace Limestone dips steeply south, quarried intermittently from 1947 to 1950, several thousand tons shipped to Los Angeles for use as whiting. (Wright and others, 1953, p. 174)

BB. White Rock Limestone Co. quarry. NW $14 \mathrm{sec}$. 32 , T. 3 N., R. 2 E. White limestone marble of Furnace Limestone dips steeply south. Several hundred tons quarried intermittently since 1949 for use as roofing granules. (Wright and others, 1953, p. 181)

CC. Parton Limestone Products Co. quarry. NK/2 sec. 21 (projected), T. 3 N., R. 2 E. White limestone marble (reported 98 percent calcite) of Furnace Limestone, dips steeply south, intruded by diorite. Marble quarried since 1961, shipped to San Bernardino for use as roofing granules.

\section{Clay}

DD. Cushenbury Clay quarry. NW/4 sec. 9, T. 3 N., R. 1 E. Light reddish-brown claystone and siltstone of Old Woman Sandstone with some strata that contain quartzite pebbles and cobbles, quarried since 1958 for "clay" fraction source of alumina, silica, and iron for cement at Cushenbury plant of Permanente Cement Company. (Gray, 1960, p. 66, in part)

\section{Dimension stone}

EE. Texas Granite quarry. N多 sec. 29, T. 5 N., R. 2 E. Two small quarries in quartz monzonite each about 200 feet long, 100 feet wide, and 20 to 40 feet deep. Rock split, sawed for building stone. Quarried intermittently since 1950. (Wright and others, 1953, p. 163)

FF. Swanson quarry. SW 44 sec. $30, N W / 4$ sec. 31 , T. 5 N., R. 2 E. Also smaller quarry, now abandoned, in NW/ sec. 36, T. 5 N., R. 1 E. Small quarries in quartz monzonite, rock split, sawed; small tonnage shipped intermittently since 1950. (Wright and others, 1953 , p. 163,164 )

\section{Ornamental stone}

GG. Gold Mountain stone. Secs. 6, 7, T. 2 N., R. 2 E., secs. 1, 12, T. 2 N., R. 1 E. (14 claims). Blocks and slabs of Saragossa Quartzite with surface of red, orange, and lavender, shipped from talus or small quarries for ornamental stones occasionally since 1949. (Wright and others, 1953, p. 162)

\section{Quartz}

HH. Outcrops of quartz, one in NW cor. sec. 10, two in SW $\frac{1}{4}$ sec. 10, T. 2 N., R. 1 E., east of Baldwin Lake. Each outcrop small pod as wide as 10 feet of white massive quartz in gneiss. Prospected by shallow pits.

\section{REFERENCES}

Gray, C. H., Jr., 1960, Tabulated list of mines and mineral deposits in an area of the San Bernardino Mountains north of Big Bear Lake, San Bernardino County, California, in Richmond, J. F., Geology of the San Bernardino Mountains north of Big Bear Lake, California: California Div. Mines Spec. Rept. 65, p. 59-68.

Guillou, R. B., 1953, Geology of the Johnston Grade area, San Bernardino County, California: California Div. Mines Spec. Rept. 31, 18 p.

Richmond, J. F., 1960, Geology of the San Bernardino Mountains north of Big Bear Lake, California: California Div. Mines Spec. Rept. 65, 68p.

Vaughan, F. E., 1922, Geology of the San Bernardino Mountains north of San Gorgonio Pass [California]: California Univ. Dept. Geol. Sci. Bull., v. 13, no. 9, p. 319-411.

Woodford, A. O., and Harris, T. F., 1928, Geology of Blackhawk Canyon, San Bernardino Mountains, California: California Univ. Dept. Geol. Sci. Bull., v. 17, p. 265-304.

Wright, L. A., Stewart, R. M., Gay, T. E., Jr., and Hazenbush, G. C., 1953, Mines and mineral deposits of San Bernardino County, California: California Jour. Mines and Geology, v. 49, nos. 1 and 2, p. 49-257, with tabulated list, 192 p. 